\title{
Influence of Sapropel, Diatomite, Brown Coal and Vermicompost in Normal and Ultrafine Forms on Productivity and Quality of Spring Barley
}

\author{
Rasim Gazizov*, Irina Sukhanova, Elena Prishchepenko and Valentin Sidorov \\ TatarSRIAC SS - Subdivision of FIC KazanSC of RAS, Kazan, 420059, Republic of Tatarstan, Russia
}

\begin{abstract}
The article presents the findings on the use of foliar treatment with suspensions of sapropel, vermicompost, diatomite of conventional grinding and in ultrafine form. Fertilizers, ground to the smallest particles in deionized water under the action of ultrasound, have a high stimulating effect on the crop and have shown better results compared to conventional milled fertilizers. The yield of spring barley of the Prairia variety non-foliar treatment with these fertilizers contributed to an increase in the grain yield of spring barley of the Prairia variety up to $22.1 \%$. Analysis of the structure of the yield and the chemical composition of grain has showed that diatomite, sapropel and especially vermicompost both in the usual form and especially in the ultradispersed form affect the change in indicators in comparison with the fertilized background.
\end{abstract}

\section{Introduction}

There is a scientifically substantiated need to provide the domestic agro-industrial complex with new highly effective fertilizers, ameliorants, ensuring an increase in the yield and stability of agricultural crops in adverse environmental conditions, obtaining environmentally friendly products and eliminating the loss of food quality during storage. In recent years, close attention has been paid to their search. This issue is especially acute due to the high cost of industrial mineral fertilizers and the need to involve minerals having a minimum load on the biosphere into production activities $[1,2]$.

On the basis of images of the surface of the studied nanostructured substances, a tendency to an increase in the specific surface area of agrominerals with a change in their physical properties under ultrasonic action was revealed. Fine grinding (less than $0.1 \mathrm{~mm}$ ) significantly increases the active surface of fertilizer particles, the dissolution of the soil solution in weak acids, improves the assimilation of the complex of nutrients by plants and increases the yield of agricultural crops [3, 4].

Among nanodispersions, the nanosuspensions consisting of nanoparticles freely distributed in the volume of a liquid are most widely used. Nanosuspensions containing nanoparticles of various chemicals as well as metal particles with a pesticidal effect are promisingly used for treating plants and seeds [5].

The aim of the research was to develop technologies for the use of highly effective nanostructured substances (from organic-mineral raw materials) capable of providing a complex effect in relation to the growth, development, productivity of agricultural crops and product quality.

\section{Materials and research methods}

Diatomite, vermicompost and sapropel being ecologically safe substances created by nature itself were studied as a supplement to the doses of mineral fertilizers.

The composition of sapropel, vermicompost and diatomite enables to use them in agricultural production as additional nutrients to basic fertilizers. The use of ecological natural materials with organomineral components and their ultradispersed analogues for the treatment of seeds and plants is of the greatest relevance and enables to reduce the amount of traditional fertilizers and improve the quality of grain.

The effect of fertilizers in conventional and ultradispersed forms was studied in a field experiment according to the method of B.A. Dospekhova [6].

The experiment was repeated three times, the placement of the plots was randomized. Barley of the "Prairia" variety was used in the experiment. The soil was gray forest medium loamy and had the following characteristics: humus $-3.2 \%, \mathrm{pH}_{\mathrm{KCl}}-6.23, \mathrm{Ng}-$ 1.03 meq per $100 \mathrm{~g}$ of soil, the sum of absorbed bases 39.6 meq per $100 \mathrm{~g}$ of soil, $\mathrm{N}_{\text {acid }}-98.0 \mathrm{mg} / \mathrm{kg}, \mathrm{P}_{2} \mathrm{O}_{5}-$ $184.0 \mathrm{mg} / \mathrm{kg}, \mathrm{K}_{2} \mathrm{O}-106 \mathrm{mg} / \mathrm{kg}$.

\footnotetext{
Corresponding author: RasG77@yandex.ru
} 
The experiments used sapropel deposits of Lake Beloe RT, diatomite of the Inzensky deposit of the Ulyanovsk region, biohumus produced by "Green-PIK" (Kovrov, Vladimir region) in the form of aqueous suspensions.

Sapropel composition, \% (on dry matter): organic matter - 31.3; $\mathrm{H}-7.8 ; \mathrm{CaO}-18.9 ; \mathrm{SiO}_{2}-11,7 ; \mathrm{Al}_{2} \mathrm{O}_{3}-$ 5,1; Ntot. - 1.23; $\mathrm{P}_{2} \mathrm{O}_{5}-0,45 ; \mathrm{K}_{2} \mathrm{O}-0.82 ; \mathrm{SO}_{3}-1.27$; $\mathrm{Fe}_{2} \mathrm{O}_{3}-2.42$; humidity - 59; trace elements - Mn, Cu, $\mathrm{Zn}$, etc., not exceeding the MAC. Diatomite composition (in oxide form, $\%$ on absolutely dry matter): $\mathrm{SiO}_{2}$ 83.5; $\mathrm{Al}_{2} \mathrm{O}_{3}-7.74 ; \mathrm{Fe}_{2} \mathrm{O}_{3}-2.40 ; \mathrm{K}_{2} \mathrm{O}-1.25 ; \mathrm{MgO}-$ 0.56; $\mathrm{CaO}-0.48 ; \mathrm{TiO}_{2}-0.28 ; \mathrm{FeO}-0.13 ; \mathrm{P}_{2} \mathrm{O}_{5}-0.05$; $\mathrm{Na}_{2} \mathrm{O}-0.02 ; \mathrm{MnO}-0.01 ; \mathrm{SO}_{3}-0.32$; amorphous $\mathrm{SiO}_{2}-$ 42.0. Vermicompost composition, \%: organic matter 30.0; $\mathrm{pH}-7.5 ;$ Ntot - 1.85; $\mathrm{P}_{2} \mathrm{O}_{5}-1.78 ; \mathrm{K}_{2} \mathrm{O}-2,33$; $\mathrm{CaO}-1.03$; humidity -35.0 ; contains a complex of trace elements, the presence of salts of heavy metals is negligible.

\section{Research results}

The decomposition of linen fabric in vessels by soil microorganisms was minimal this year. Microbiological studies of linen sheets did not reveal the presence of cellulose-destroying microorganisms. With the appearance of septoria on barley leaves, watering of plants in vessels was reduced. There was not enough moisture for tissue decay, and the activity of cellulosedestroying microorganisms slowed down. To combat septoria, the biological preparation Pseudobacterin-2, Zh (foliar treatment of plants) was used. In the field, the manifestation of the disease was less noticeable.

The data on the composition and number of micromycetes are presented in Table 1.

Table 1. Statistical indicators of grey forests heavy loam arable soils, $\%$

\begin{tabular}{|c|c|c|}
\hline No. & Variant & $\begin{array}{c}\text { Number of } \\
\text { micromycetes in } \\
\text { harvesting phase, } \times \\
\mathbf{1 0}^{6} \text { CFU/g }\end{array}$ \\
\hline 1 & Ground N60 $\mathrm{P}_{60} \mathrm{~K}_{60}$ & 0.2 \\
\hline 2 & $\begin{array}{c}\text { Ground + pre-sowing seed } \\
\text { treatment with sapropel } \\
\text { suspension at a dose of } 1.5 \mathrm{~kg} / \mathrm{t}\end{array}$ & 0.2 \\
\hline 3 & $\begin{array}{c}\text { Ground + pre-sowing seed } \\
\text { treatment with vermicompost } \\
\text { suspension at a dose of } 1.5 \mathrm{~kg} / \mathrm{t}\end{array}$ & 0.25 \\
\hline 4 & $\begin{array}{c}\text { Ground + pre-sowing seed } \\
\text { treatment with diatomite } \\
\text { suspension at a dose of } 1.5 \mathrm{~kg} / \mathrm{t}\end{array}$ & 0.6 \\
\hline 5 & $\begin{array}{c}\text { Ground + pre-sowing seed } \\
\text { treatment with nanosapropel } \\
\text { suspension at a dose of } 1.5 \mathrm{~kg} / \mathrm{t}\end{array}$ & 0.3 \\
\hline 6 & $\begin{array}{c}\text { Ground + pre-sowing seed } \\
\text { treatment with nanobiohumus } \\
\text { suspension at a dose of } 1.5 \mathrm{~kg} / \mathrm{t}\end{array}$ & \\
\hline 7 & $\begin{array}{c}\text { Ground + pre-sowing seed } \\
\text { treatment with nanodiatomite } \\
\text { suspension at a dose of } 1.5 \mathrm{~kg} / \mathrm{t}\end{array}$ & 0.35 \\
\hline
\end{tabular}

The maximum indices of the number of micromycetes were observed in the variant with the use of diatomite suspensions as pre-sowing seed treatment. Seed treatment with vermicompost and diatomite in ultrafine form also had a significant effect on the active growth of micromycetes.

When analyzing the qualitative composition only in the variant with the use of nanostructured biohumus, fungi of the genus Trichoderma were revealed, which was a positive fact since they have a depressing effect on pathogenic fungi. Trichoderma harzianum is an antagonist of filamentous fungi of plant pathogens used for the biological control of diseases caused by phytopathogenic fungi. It is widely used in agriculture due to its properties as biofungicides, biofertilizers and biostimulants. Its normal development takes place in areas where organic plant material accumulates.

The grain yield is determined by the individual elements of the yield structure. This is an integral indicator, including the fulfillment of the productivity potential of the plant in the genome with the state of environmental factors and modern technological methods used as a means for the full manifestation of the metabolic processes of the cultivated crop [7] The yield of spring barley in the field experiment is presented in table 2.

Table 2. Influence of foliar treatment of plants on the yield of barley, t/ha

\begin{tabular}{|c|c|c|c|}
\hline \multirow{2}{*}{ Variant } & \multirow[t]{2}{*}{$\begin{array}{c}\text { Average } \\
\text { grain yield }\end{array}$} & \multicolumn{2}{|c|}{$\begin{array}{c}\text { Supplement, } \\
+/-\%\end{array}$} \\
\hline & & to control & to ground \\
\hline 1. Control & 2.71 & - & - \\
\hline 2. $\mathrm{N}_{60} \mathrm{P}_{60} \mathrm{~K}_{60}-$ ground & 3.30 & +21.8 & - \\
\hline $\begin{array}{l}\text { 3. Ground }+ \text { treatment of } \\
\text { plants with } 0.5 \% \text { sapropel } \\
\text { suspension }\end{array}$ & 3.59 & +32.5 & +8.8 \\
\hline $\begin{array}{l}\text { 4. Ground + treatment of } \\
\text { plants with } 0.5 \% \\
\text { vermicompost suspension }\end{array}$ & 3.86 & +42.4 & +17.0 \\
\hline $\begin{array}{l}\text { 5. Ground }+ \text { treatment of } \\
\text { plants with } 0.5 \% \text { diatomite } \\
\text { suspension }\end{array}$ & 3.70 & $+36,5$ & $+12,1$ \\
\hline $\begin{array}{l}\text { 6. Ground }+ \text { treatment of } \\
\text { plants with } 0.5 \% \text { sapropel } \\
\text { suspension in ultrafine form }\end{array}$ & 3.70 & +36.5 & +12.1 \\
\hline $\begin{array}{l}\text { 7. Ground }+ \text { treatment of } \\
\text { plants with } 0.5 \% \\
\text { suspension of } \\
\text { vermicompost in ultrafine } \\
\text { form } \\
\end{array}$ & 4.03 & +48.7 & +22.1 \\
\hline $\begin{array}{l}\text { 8. Ground }+ \text { treatment of } \\
\text { plants with } 0.5 \% \\
\text { suspension of diatomite in } \\
\text { ultrafine form }\end{array}$ & 3.88 & +43.2 & +17.6 \\
\hline $\mathrm{LSD}_{05}$ & & & \\
\hline
\end{tabular}

Two-fold foliar treatment of plants with macrosuspensions of sapropel, vermicompost, diatomite enabled to increase the yield of barley by $8.8-17 \%$, and the ultradispersed treatment - by $12.1-22.1 \%$ relative to the ground. The best indicators of grain gain were 
obtained in versions with the use of biohumus rich in organic matter. It should be noted that the culture responded better to a macro-suspension of vermicompost with an increase in yield, which, in our opinion, is explained by better solubility and better absorbtion by plant tissues. In addition, vermicompost is rich in nutrients essential for crops growth and development. Sapropel and diatomite also contributed to the increase in crop yields.

The use of these substances as ameliorants, fertilizers and growth stimulants with the objective to improve the agrochemical, agrophysical and biological properties of the soil in plant growing is due to the presence of biogenic macro- and microelements, high ion exchange, sorption and catalytic properties [8]. The increase in grain was 8.8 and $12.1 \%$ to the background, respectively.
Such preparations, unlike traditional chemicals, ensure complete wetting of the plant surface, are completely absorbed by the plants, and not washed off by rain. They are distinguished by the maximum penetration of active substances into leaves, stems and roots. Their use enables to achieve a significant effect with minimal doses of drugs. Tests of drugs in this form show that they have increased biological activity, due to which the rates of their consumption can be significantly reduced $[6,9]$.

The advantage of suspensions with ultrafine particles of vermicompost and diatomite in comparison with macro analogs was up to $5 \%$. The treatment of plants with the studied organomineral suspensions made it easier for nutrients to penetrate through the stems and leaves. To determine the structure of the crop, before harvesting barley, sheaves were selected and the indicators between the options were analyzed (Table 3 ).

Table 3. Prairie barley crop structure

\begin{tabular}{|c|c|c|c|c|c|c|c|}
\hline \multirow[t]{2}{*}{ Variants } & \multirow{2}{*}{$\begin{array}{c}\text { Plant } \\
\text { height, } \\
\text { cm }\end{array}$} & \multirow{2}{*}{$\begin{array}{c}\text { Ear } \\
\text { length, } \\
\mathrm{cm}\end{array}$} & \multirow{2}{*}{$\begin{array}{c}\text { Number } \\
\text { of grains, } \\
\text { pcs/ear }\end{array}$} & \multirow{2}{*}{$\begin{array}{c}\text { Weight of } \\
1,000 \\
\text { grains, } g\end{array}$} & \multicolumn{3}{|c|}{ Weight } \\
\hline & & & & & $\begin{array}{c}\text { plants, } \\
\text { g/m }\end{array}$ & $\begin{array}{c}\text { roots, } \\
\text { g/m } \mathbf{m}^{2}\end{array}$ & $\begin{array}{c}\text { seeds, } \\
\text { g/m } \mathbf{m}^{2}\end{array}$ \\
\hline 1. Control & 57.7 & 5.3 & 15 & 39.21 & 780 & 19.0 & 265.0 \\
\hline 2. $\mathrm{N}_{60} \mathrm{P}_{60} \mathrm{~K}_{60}-$ ground & 62.8 & 5.8 & 16 & 40.32 & 975 & 25.5 & 307.1 \\
\hline $\begin{array}{l}\text { 3. Ground + plants treatment with } 0.5 \% \text { sapropel } \\
\text { suspension }\end{array}$ & 64.7 & 5.8 & 17 & 41.34 & 1050 & 30.0 & 310.4 \\
\hline $\begin{array}{l}\text { 4. Ground + plants treatment with } 0.5 \% \text { vermicompost } \\
\text { suspension }\end{array}$ & 64.6 & 5.9 & 18 & 41.18 & 1000 & 33.0 & 320.4 \\
\hline $\begin{array}{l}\text { 5. Ground + plants treatment with } 0.5 \% \text { diatomite } \\
\text { suspension }\end{array}$ & 63.9 & 5.9 & 18 & 40.74 & 1050 & 32.5 & 308.0 \\
\hline $\begin{array}{l}\text { 6. Ground + plants treatment with } 0.5 \% \text { sapropel } \\
\text { suspension in ultrafine form }\end{array}$ & 72.1 & 6.1 & 20 & 43.93 & 1010 & 30.5 & 307.9 \\
\hline $\begin{array}{l}\text { 7. Ground + plants treatment with } 0.5 \% \text { suspension of } \\
\text { vermicompost in ultrafine form }\end{array}$ & 67.5 & 6.0 & 19 & 42.66 & 1150 & 42.5 & 335.9 \\
\hline $\begin{array}{l}\text { 8. Ground }+ \text { plants treatment with } 0.5 \% \text { suspension of } \\
\text { diatomite in ultrafine form }\end{array}$ & 63.3 & 6.1 & 20 & 42.42 & 1125 & 42.0 & 322.7 \\
\hline $\mathrm{LSD}_{05}$ & 3.47 & 0.34 & 3.55 & 1.03 & 77.8 & 3.21 & 22.13 \\
\hline
\end{tabular}

The plants height varied, on average, from $57.7 \mathrm{~cm}$ to $72.1 \mathrm{~cm}$, according to experiment. The best indicator was noted in the variant with nanosapropel, where the height of the stems averaged $9.3 \mathrm{~cm}(14.8 \%)$ and $14.4 \mathrm{~cm}(25 \%)$ relative to the background and control, respectively, in relation to sapropel in the usual form $7.4 \mathrm{~cm}$. Ultradispersed vermicompost also led to results that exceeded those for other variants. During filling and ripening of the barley grain, the straw at the base of the ear bends, and the ear is inside the stalk but the straw does not break and the loss of ears is not observed. The best average spike length being $6.1 \mathrm{~cm}$ was as well revealed in variants with the use of nanostructured sapropel of $b$ diatomite. The number of grains reached 20 pieces per ear, the average amount was 18 pieces per ear. In terms of the number of grains in an ear, the use of nanosubstances was effective as well. The average size of ears according to the variants changed insignificantly. Specifically, they changed up to $0.3 \mathrm{~cm}$ in comparison with the ground, and the maximum length was obtained when processing with ultradispersed fertilizer suspensions.
Plants treated with a suspension of vermicompost and diatomite of normal grinding, on average, formed 2 more seeds than in the variant with the ground.

The mass of 1,000 grains was also higher in all the studied variants, and a more complete grain was obtained from the samples treated with fertilizers containing nanoparticles. The increase in grain mass in these variants reached $9 \%$ to the ground, and the best indicator was obtained with the use of sapropel.

The weight of plants without ears and roots averaged $780-1150 \mathrm{~g} / \mathrm{m}^{2}$. The use of nanostructured suspensions of diatomite and vermicompost contributed to an increase in weight by 75 and $150 \mathrm{~g}$, respectively. Advantageous in terms of the indicator were the variants with foliar treatment with ultrafine suspension of diatomite and vermicompost. Plants actively absorb silicon, which is in an amorphous form in diatomite and has a mechanism for its rapid redistribution throughout the body. Active forms of silicon are capable of controlling many biochemical reactions in plants. Foliar treatment of plants with silicon-rich diatomite had a protective effect on productivity elements.

In the barley of Prairie variety, both embryonic and nodal roots are well developed, which, to a certain 
extent, determines such qualities as high heat resistance and drought resistance. The air-dry biomass of roots in the experiment varied from 19 to $42 \mathrm{~g} / \mathrm{m}^{2}$. The root system reached the maximum weight using vermicompost and diatomite in ultrafine form. In these variants, the weight of the roots significantly exceeded the indices of plants when applying mineral fertilizers and the studied fertilizers of conventional grinding.

It is difficult to say how effective was plants treatment with suspensions for increasing the mass of roots, but, presumably, receiving additional nutrition from the outside favored plant growth and stimulated the development of the root system.

According to the Federal State Budgetary Institution of the State Variety Commission, the Prairie spring barley variety is classified as valuable in terms of quality as it consists of $80-88 \%$ of dry matter and $12-20 \%$ of water. Dry matter is the sum of organic and inorganic substances. Organic matter is mainly carbohydrates and proteins, as well as fats, polyphenols, organic acids, vitamins and other substances. Inorganic substances are phosphorus, sulfur, silicon, potassium, sodium, magnesium, calcium, iron, chlorine. Some of them are associated with organic compounds.

Table 4. Influence of foliar processing of barley plants on the chemical composition of grain, $\%$

\begin{tabular}{|c|c|c|c|c|c|}
\hline Variants & Ash & Nitrogen & Protein & $\mathbf{P}_{\mathbf{2}} \mathbf{O}_{\mathbf{5}}$ & $\mathbf{K}_{\mathbf{2}} \mathbf{O}$ \\
\hline 1. Control & 2.33 & 1.7 & 9.4 & 0.8 & 0.48 \\
\hline 2. $\mathrm{N}_{60} \mathrm{P}_{60} \mathrm{~K}_{60}$ - Ground & 2.34 & 1.73 & 9.5 & 0.92 & 0.50 \\
\hline $\begin{array}{c}\text { 3. Ground + plants } \\
\text { treatment with 0.5 \% } \\
\text { sapropel suspension }\end{array}$ & 2.40 & 1.77 & 9.7 & 0.89 & 0.54 \\
\hline $\begin{array}{c}\text { 4. Ground + plants } \\
\text { treatment with 0.5 \% } \\
\text { vermicompost suspension }\end{array}$ & 2.38 & 1.70 & 9.4 & 0.96 & 0.80 \\
\hline $\begin{array}{c}\text { 5. Ground + plants } \\
\text { treatment with 0.5 \% } \\
\text { diatomite suspension }\end{array}$ & 2.52 & 1.79 & 9.8 & 1.02 & 0.82 \\
\hline $\begin{array}{c}\text { 6. Ground + plants } \\
\text { treatment with 0.5 \% } \\
\text { sapropel suspension in } \\
\text { ultrafine form }\end{array}$ & 2.40 & 1.83 & 10.0 & 1.13 & 0.72 \\
\hline $\begin{array}{c}\text { 7. Ground + plants } \\
\text { treatment with 0.5 \% } \\
\text { suspension of } \\
\text { vermicompost in ultrafine } \\
\text { form }\end{array}$ & 2.49 & 1.80 & 9.9 & 1.00 & 0.70 \\
\hline $\begin{array}{c}\text { 8. Ground + plants } \\
\text { treatment with 0.5 \% } \\
\text { suspension of diatomite } \\
\text { in ultrafine form }\end{array}$ & 2.59 & 1.83 & 10.0 & 1.1 & 0.81 \\
\hline
\end{tabular}

The ash content in the experiment varied from 2.33 to $2.59 \%$. The ash content during treatment with ultrafine vermicompost and diatomite was the maximum according to the experiment and increased in comparison with the ground by 6.4 and $10.7 \%$, respectively. A high ash content was noted in the variant with the treatment of plants with a suspension of diatomite of ordinary grinding; in comparison with the ground, the content increased by $7.7 \%$
The nitrogen content in the grain of spring barley was 1.7-1.83 \% and the maximum accumulation was obtained in plants treated with ultrafine sapropel and diatomite. The protein content in the grain correlated with the amount of nitrogen and was $9.4-10.0 \%$ in the field experiment depending on the variant.

Brewing barley is characterized by a lower protein content in the grain, the optimum of which is 9.5-10.0\%, which is consistent with our data and the possibility of obtaining a product of good quality. The treatment of plants with sapropel and diatomite in ultradispersed forms proved to be more effective than their macroanalogues.

The phosphorus content in the grain was also higher in the variants with nanosapropel and nanodiatomite. The increase in content to macrosuspensions was $0.74 \%$. The increase in the phosphorus content in the grain in the experiments was $1.1-1.9 \%$ relative to the ground application of fertilizers. The content of potassium in barley grain also increased in relation to the control and ground variants in the field experiment and amounted to $0.34 \%$.

The use of ultradispersed (nanostructured) suspensions for foliar feeding of spring barley plants accelerated the growth and development of the plant organism, ensured an effective increase in yield, and enabled to obtain ecologically safe agricultural products with improved biochemical characteristics.

\section{Conclusion}

The studied fertilizers, especially in ultradispersed form, contributed to the improvement of the indicators of the crop structure elements. Foliar treatment of plants with ultrafine sapropel and vermicompost had the best effect on the development of barley and influenced the length, weight of plants and the weight of 1,000 grains. When treating seeds with nanobiohumus, the best indicators of the length of plants and ears were noted, and in terms of the mass of 1,000 grains and the weight of plants, the variant with nanostructured diatomite was in priority.

The stimulating effect of natural fertilizers to increase the yield of barley has been revealed. The increase in grain was up to $22.1 \%$, the best yield indicator was obtained when using a suspension of vermicompost, diatomite in ultradispersed forms.

Nanosuspensions possessing unique properties due to individual particle sizes of 50-60 nm, penetrating freely without damaging the structure and stimulating biochemical processes without consequences for the plant organism have increased the qualitative and quantitative indicators of the manufactured crop products.

\section{References}

1. B. Zaimenko, N. Didyk, N. Ellanska, B. Ivanytska, N. Pauluchenko, D. Rakhmetov, I. Kharytonova, Sci. and innovat., 12, 58-68 (2016) 
2. A. Yapparov, L. Bikkinina, I. Yapparov, Sh. Aliev, A. Ezhkova, V. Ezhkov, R. Gazizov, Euras. Soil Sci., 48, 1149-1158 (2015)

3. A. Yapparov, Sh. Aliev, I. Yapparov et al., Scientific substantiation of obtaining nanostructured and nanocomposite materials and technology of their use in agriculture (Center of Innovat. Technol. LLC, Kazan, 2014), 304 p.

4. N. Sharonova, A. Yapparov, N. Khisamutdinov, A. Ezhkova, I. Yapparov, V. Ezhkov, I. Degtyareva, E. Babynin, Nanostructured water-phosphorite suspension is a new promising fertilizer, Nanotechnol. in Russ., 10, 651-661 (2015)

5. S. Zhdanyuk, Z. Ilyina, N. Tolochko, Nanotechnology in the agro-industrial complex, ed. by N.K. Tolochko (BGATU, Minsk, 2012), 172 p.
6. B. Dospekhov, Field experiment technique (with the basics of statistical processing of research results) (5nd ed., add. and rev.) (Agropromizdat, Moscow, 1985), $351 \mathrm{p}$.

7. N. Alekhina et al., Plant physiology (Academy, Moscow, 2005), 640 p.

8. R. Abuzyarov, F. Idiatullin, F. Akhmetov et al., Agromineralnye resources of Tatarstan and the prospects for their use, Monograph, under the general ed. A.V. Yakimova (Feng, Kazan, 2002), 272 p.

9. L. Nesterova, L. Elinevskaya, L. Berezina, New technologies of the formulation of pesticides, Agrochem., 1, 33-37 (2009) 